\title{
Camaenid land snails on Barrow Island: distributions, molecular phylogenetics and taxonomic revision
}

\author{
Michael S. Johnson', Sean Stankowski', Corey S. Whisson², Roy J. Teale ${ }^{1,3}$ \\ and Zoë R. Hamilton'
}

\author{
${ }^{1}$ School of Animal Biology (M092), University of Western Australia, Crawley, Western Australia 6009, \\ Australia. Email: mike.johnson@uwa.edu.au. \\ 2 Western Australian Museum, Locked Bag 49, Welshpool, Western Australia 6106, Australia. \\ ${ }^{3}$ Biota Environmental Sciences Pty Ltd, PO Box 155, Leederville, Western Australia 6903, Australia. \\ Corresponding author: Michael Johnson, School of Animal Biology (M092), University of Western \\ Australia, 35 Stirling Highway, Crawley, WA 6009. Email: mike.johnson@uwa.edu.au
}

\begin{abstract}
Three species of camaenid land snails occur on Barrow Island: Quistrachia barrowensis and two previously unassigned species of Rhagada. Based on morphological re-evaluation and analysis of sequences of the mitochondrial gene COI, we have revised the taxonomy of these species, providing a clearer understanding of their geographic distributions and origins. The supposed Barrow Island endemic $Q$. barrowensis is synonymous with $Q$. montebelloensis from the Montebello and Lowendal Islands. The small species of Rhagada, confined to the northern tip of Barrow Island, is conspecific with $R$. plicata, whose distribution also includes the Montebellos and the Lowendals. The large species of Rhagada is described here as $R$. barrowensis sp. nov., known only from Barrow Island and adjacent Pascoe Island. The three camaenids represent deeply divergent lineages with different geographic origins, indicating that the local diversity on Barrow Island has come about through a complex history. With maximum geographic spans of only 22 to $70 \mathrm{~km}$, the short-range endemism of these species highlights the conservation significance of Barrow Island.
\end{abstract}

KEYWORDS: COI mtDNA, endemic species, phylogeny, Quistrachia, Rhagada

\section{INTRODUCTION}

The Camaenidae are the dominant land snails across northern and eastern Australia, including the Pilbara region. They are represented on Barrow Island by three species from two genera (Solem 1997; Slack-Smith 2002; Johnson et al. 2006) (Figure 1). The most species-rich camaenid genus in the Pilbara region is Rhagada Albers, 1860 (Solem 1997), which is represented on Barrow by two distinct, unidentified species, which differ markedly in size, banding and sculpture of the shell (Johnson et al. 2006). Except for a brief mention of small, worn, dead shells, Solem's (1997) taxonomic review did not include Rhagada from Barrow Island. Although Withers et al. (1997) referred to the larger species as R. tescorum, this was tentative, and the species' morphological similarities to other species have rendered its taxonomic status unclear (Slack-Smith 2002). The second most species-rich camaenid genus in the Pilbara is Quistrachia Iredale, 1939, within which Solem (1997) described Quistrachia barrowensis as an endemic species on Barrow Island and its associated islets. In this paper, we document the distributions of all three camaenids on the island, and revise their taxonomy, based on analyses of DNA sequences and morphology.

The Quistrachia on Barrow Island and associated islets was described as $Q$. barrowensis by Solem (1997). Its relatively thick shells are similar to those of $Q$. lefroyi from the Cape Range and Ningaloo Station and $Q$. warroorana from Warroora and Gnaraloo stations (Solem 1997). These species are free-sealers during aestivation, and phylogenetic analysis indicates that they are a separate clade from that of the rock-sealers $Q$. legendrei from the Dampier Archipelago and Burrup Peninsula and $Q$. turneri from the inland Pilbara, which have thinner shells and flared apertures ( $\mathrm{O}^{\prime} \mathrm{Neill}$ 2008). That phylogenetic analysis did not include the fourth 


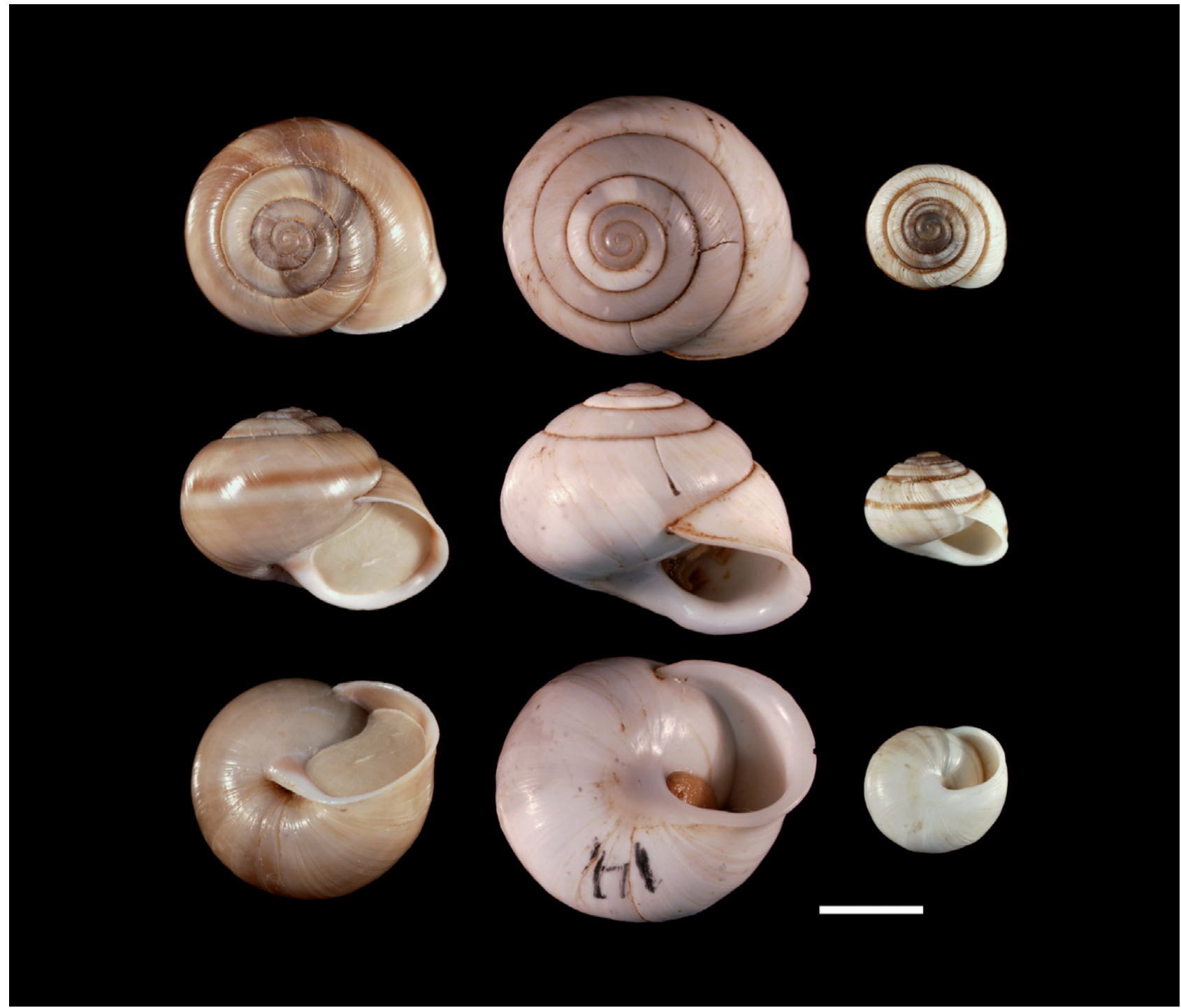

FIGURE 1

Examples of the three camaenid species on Barrow Island. From left to right: Quistrachia montebelloensis (= Q. barrowensis), the large Rhagada (holotype of Rhagada barrowensis sp. nov.), and the small Rhagada. Note the epiphragm in $Q$. montebelloensis. Scale bar $=1 \mathrm{~cm}$.

free-sealer, Q. montebelloensis, from the Montebello Islands, which is morphologically very similar to Q. barrowensis (Solem, 1997), and which has been included in the present study.

In the genus Rhagada, analysis of mtDNA sequences in all described species in the Pilbara region has revealed four, deep lineages, two of which are represented on Barrow Island (Johnson et al. 2012). The small species on Barrow Island is genetically very close to $R$. plicata from the Montebello Islands, as part of the lineage that also includes all but one of the species endemic to the Dampier Archipelago, but which is absent from the mainland. The large species of Rhagada from Barrow Island is part of the major mainland lineage, and is most closely related to populations of the widespread $R$. convicta from the adjacent mainland, as well as $R$. pilbarana from Mount Herbert. In the present study of Rhagada, we examine additional samples from Barrow Island, the Montebello Islands and the nearby Varanus Island, to clarify the relationships of both species on Barrow Island.

\section{MATERIALS AND METHODS}

\section{DISTRIBUTIONS}

The distributions of camaenid snails were determined from the WAM collections and additional surveys (Slack-Smith 2002; Johnson et al. 2006). The samples recorded in Johnson et al. (2006) 
were from searches for live snails, whereas many of the other records are of shells only. Because of close similarities of two of the species on Barrow Island with species in the Montebello Islands and the Lowendal Islands, samples from those groups were included for comparison.

\section{GENETIC ANALYSES}

Broad-scale phylogenetic analyses within both Quistrachia and Rhagada, including representatives of the Barrow Island species, have already been carried out using sequences of the mitochondrial genes 16S rRNA (16S) and cytochrome c oxidase subunit 1 (COI) (O'Neill 2008 for Quistrachia; Johnson et al. 2012 for Rhagada). Here, we added specimens specifically required to understand the relationships of the taxa on Barrow Island, and analysed these with the relevant subset of species in each genus. Because previous analyses confirmed consistency of relationships among species based on either $16 \mathrm{~S}$ or COI and based on different phylogenetic analyses (neighbour joining, Bayesian or maximum likelihood), we simply report here maximum likelihood analyses of sequences of COI, which were conducted in Mega 5 (Tamura et al. 2011). Trees are presented in linearized form, to indicate clearly the levels of divergence. Methods of DNA extraction, PCR, sequencing and analysis were as detailed in Johnson et al. (2012). COI is the usual gene used in DNA barcoding, and its use here to quantify genetic divergence allows consistent comparisons with other studies.

For Quistrachia, we include samples of $Q$. montebelloensis in the analysis of COI sequences of the four free-sealers, as well as samples of $Q$. barrowensis from Boodie Island and Pascoe Island, and similar specimens from Varanus Island in the nearby Lowendal Islands. The rock-sealer $Q$. legendrei was used as an outgroup.

To examine more fully the relationship of the small species to $R$. plicata, we increased the sample size on Barrow from two to five, and in the Montebellos from two to eight, including specimens from Hermite Island and Crocus Island. We also added specimens from Varanus Island. For the large species on Barrow Island, we added two specimens from Boodie Island to the two from Barrow examined previously. To place these in context, we included the published sequences of $R$. convicta from Exmouth, Giralia and Onslow, $R$.

\begin{tabular}{llllll} 
& ${ }^{\circ} \mathrm{S}$ & ${ }^{\circ} \mathrm{E}$ & Quistrachia & Small Rhagada & Large Rhagada \\
\hline Boodie Island & 20.9659 & 115.3335 & QU512-513 & & R837-838 \\
Boodie Island & 20.9657 & 115.3341 & & & \\
Pascoe Island & 20.9608 & 115.3396 & QA18 & & \\
Barrow Island & 20.7012 & 115.4247 & QA20, QA43 & & R819-820 \\
Barrow Island & 20.6967 & 115.4247 & QA47 & & \\
Barrow Island & 20.7012 & 115.4255 & & R533-536 & \\
Barrow Island & 20.8132 & 115.4259 & QA21-22 & & \\
Barrow Island & 20.8182 & 115.4383 & & R835-836 & \\
Barrow Island & 20.6714 & 115.4420 & & & \\
Barrow Island & 20.7311 & 115.4701 & QA05-06, QA45 & & \\
Varanus Island & 20.6476 & 115.5709 & S83637 & & \\
Varanus Island & 20.6527 & 115.5796 & S83644 & S83636 & \\
Varanus Island & 20.6556 & 115.5766 & & S83647 & \\
Varanus Island & 20.6566 & 115.5782 & & G14-16 & \\
Crocus Island & 20.4194 & 115.5259 & QU516-517 & G17-19 & \\
Hermite Island & 20.4859 & 115.5273 & & QU518-520 & \\
Hermite Island & 20.4421 & 115.5320 & &
\end{tabular}




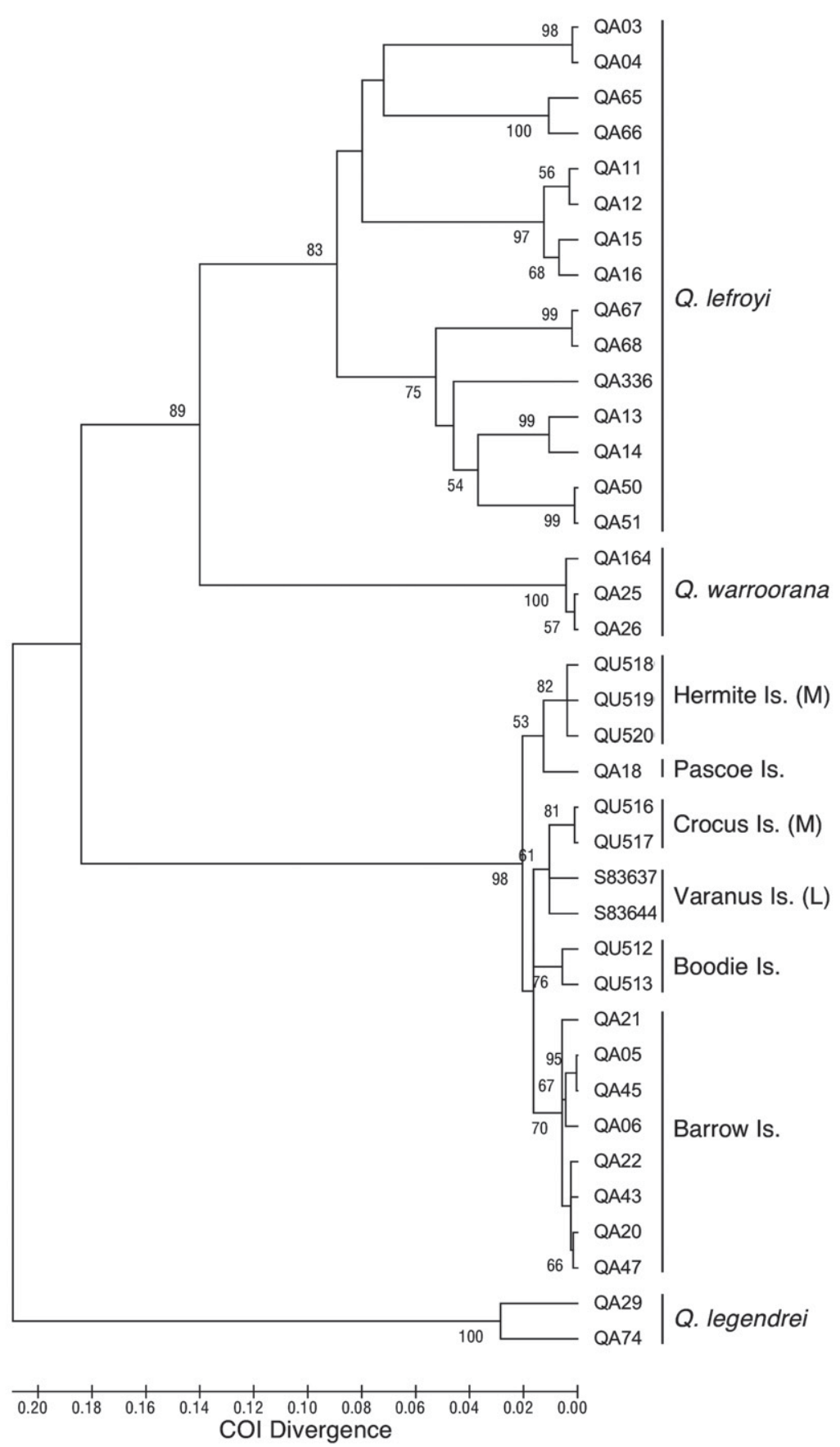

FIGURE 2 Maximum likelihood consensus tree of COI haplotypes in Quistrachia from Barrow Island and adjacent areas. (M) indicates Q. montebelloensis from the Montebello Islands; (L) indicates Lowendal Islands. Bootstrap values greater than $50 \%$ are shown. Haplotype codes are as in Table 1.

pilbarana, $R$. capensis from the Cape Range, and $R$. perprima from the Dampier Archipelago (Johnson et al. 2012). These are all the species whose shells are similar to those of the large species on Barrow Island (Solem 1997; Slack-Smith 2002). The locations of the specimens of both Rhagada and Quistrachia from Barrow Island, the Montebellos and Varanus Island that were examined for COI are shown in Table 1. The GenBank accession codes for these new sequences are KC617888 to KC617919. 


\section{RESULTS}

\section{GENETIC RELATIONSHIPS}

Haplotypes of COI in Quistrachia from Barrow Island and the associated Boodie and Pascoe Islands formed a tight clade with $Q$. montebelloensis from Hermite and Crocus Islands in the Montebellos and Varanus Island in the Lowendals, as a sister group of the mainland clade of $Q$. lefroyi and Q. warroorana (Figure 2). The haplotypes from Barrow and the Montebellos were interspersed within their clade. Genetic distances ( $p$-distance) within this clade were low, with a maximum of 0.038 . The range between $Q$. barrowensis and $Q$. montebelloensis was 0.014 to 0.038 , compared with 0 to 0.037 within species. The maximum distances were only half those seen in the diverse $Q$. lefroyi from the mainland, and also less than seen within Q. legendrei.

Haplotypes of COI from the small species of Rhagada on Barrow Island formed a clade with $R$. plicata from the Montebellos and Varanus Island (Figure 3). Although the three groups were separate clades on the tree, the genetic distances between them were low, averaging 0.022 , comparable to the

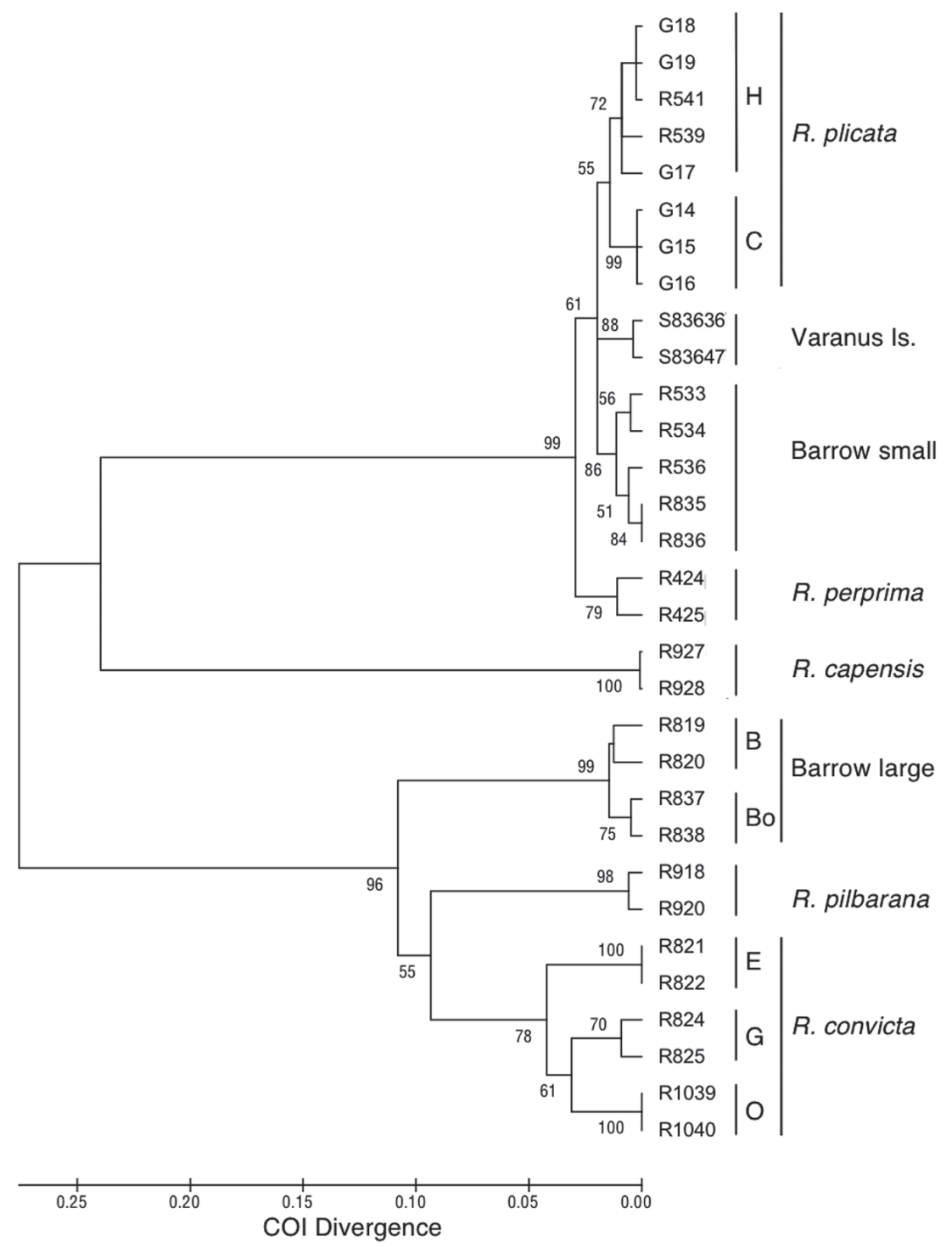

FIGURE 3 Maximum likelihood consensus tree of COI haplotypes in Rhagada from Barrow Island and contextual species. For $R$. plicata from the Montebello Islands, $\mathrm{H}=$ Hermite Island, and $\mathrm{C}=$ Crocus Island. For the large species on Barrow Island, $\mathrm{B}=$ Barrow Island and $\mathrm{Bo}=$ Boodie Island. For the mainland species $R$. convicta, $\mathrm{E}$ $=$ Exmouth, $\mathrm{G}=$ Giralia, and $\mathrm{O}=$ Onslow. Haplotype codes are as in Table 1. 


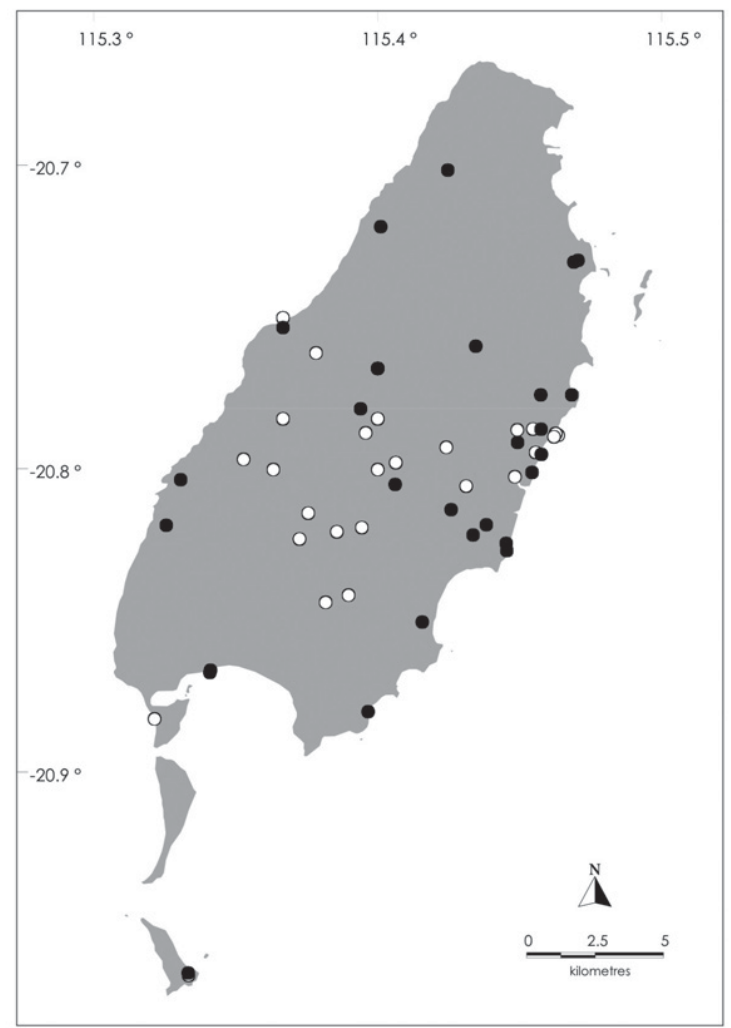

FIGURE 4

Records of the large camaenid (Rhagada barrowensis sp. nov.), on Barrow Island and adjacent Boodie Island. Filled circles indicate live-caught specimens, open circles shells only.

average distance of 0.026 between $R$. plicata from Crocus Island and those from Hermite Island. Genetic distances within the large species on Barrow were similar, averaging 0.025 between Boodie Island and the site on Barrow. The clade of this large species was well separated from its closest relatives, $R$. pilbarana and $R$. convicta, with an average genetic distance of 0.159 (Figure 3).

\section{DISTRIBUTIONS}

The large species of Rhagada is abundant and widespread on Barrow Island, occurring across most of the island, except for the northern tip, where it is replaced by the small species (Figure 4). The small species has been found only near the northern tip, and has not been found in sympatry with the large species (Figure 5). The intermediate-sized species, $Q$. barrowensis, also occurs widely on the island (Figure 6). Although the collections are not as extensive as those for the large Rhagada, casual observations indicate that $Q$. barrowensis may be more widespread and perhaps more abundant than Rhagada.

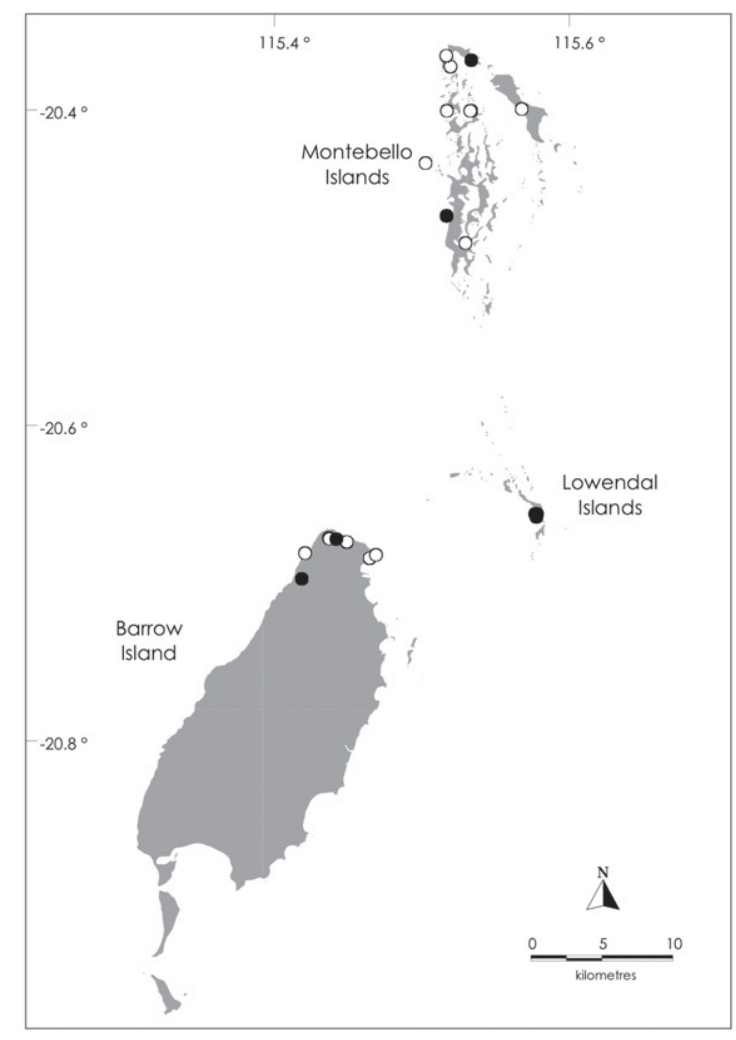

FIGURE 5

Records of the small Rhagada on Barrow Island, and $R$. plicata on the Lowendal and Montebello Islands. Filled circles indicate live-caught specimens, open circles shells only.

\section{DISCUSSION}

The genetic comparisons here help considerably to clarify the taxonomic relationships of the camaenid snails on Barrow Island. Care must be taken in the taxonomic interpretation of the sequences of COI, because the levels of sequence divergence associated with speciation vary considerably among taxa. In land snails, examples of highly divergent lineages that are reproductively compatible include the European species Cepaea nemoralis (Johnson et al., 1984; Thomaz et al., 1996; Davison and Clarke, 2000) and the slug Arion subfuscus (Pinceel et al., 2005), but in other taxa, there is reproductive isolation despite low levels of molecular divergence, such as in Partula in French Polynesia (Johnson et al., 1993; Goodacre, 2002). Based on a review of relevant studies in land snails, the best 'threshold' for delimiting species was $4 \%$ divergence for COI, but this performed poorly (Davison et al., 2009). A study combining mtDNA and reproductive anatomy with thorough sampling of Amplirhagada snails in the Bonaparte Archipelago, WA, found a clear threshold of $6 \%$ 


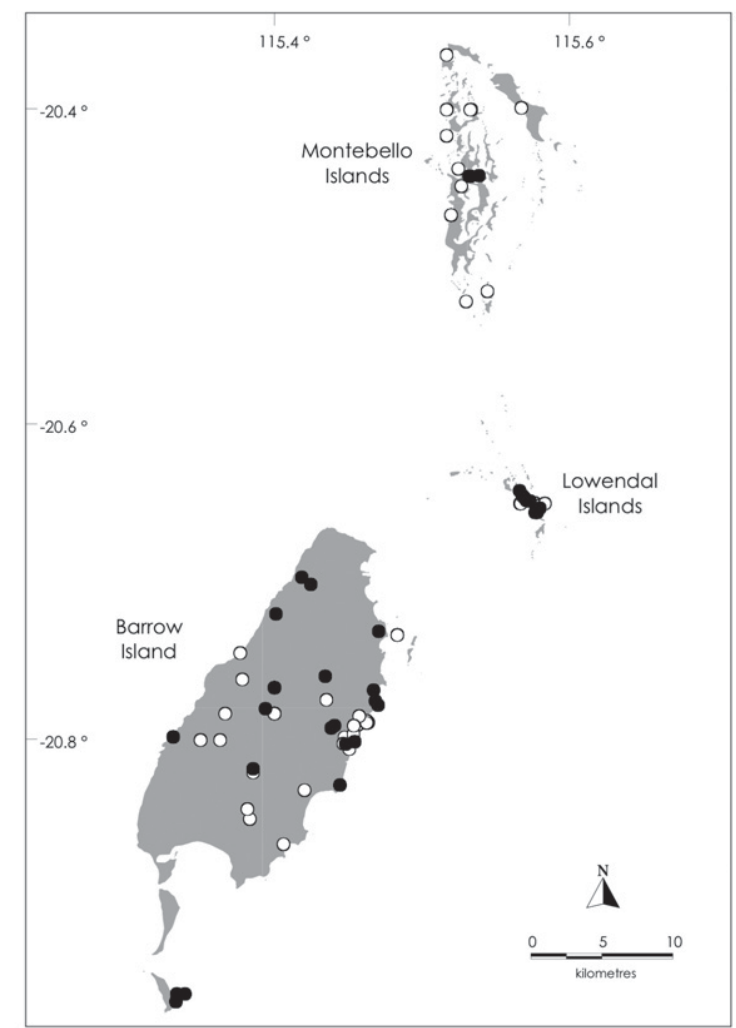

FIGURE 6

Records of Quistrachia montebelloensis (= Q. barrowensis) on Barrow Island, the adjacent Boodie and Pascoe Islands, and on the Lowendal and Montebello Islands. Filled circles indicate live-caught specimens, open circles shells only.

divergence between species (Köhler and Johnson 2012) but no gap was observed in the frequency distribution of intra- and interspecific pair-wise genetic distances.

Despite such variations, the results on Barrow Island are clear. The large species of Rhagada forms a distinct phylogenetic clade, within which divergences are $\leq 2.5 \%$. Although we have examined COI from only two sites, the previous study of allozyme variation indicated very little genetic divergence among populations across the entire island (Johnson et al. 2006), so the genetic unity of the group is clear. The mtDNA clade of the large species on Barrow is highly divergent from its nearest relatives, and the comparisons included all previously described species of Rhagada from the Pilbara region (Johnson et al. 2012). The new species from Barrow Island is formally described below.

In contrast to this endemic species, the genetic comparisons indicate that the small species of Rhagada and Quistrachia barrowensis are conspecific with species from the Montebello and Lowendal Islands. In Rhagada, the very low levels of genetic divergence support the indications from shells; the size, shape and sculpture of the small species on Barrow Island fit the description of $R$. plicata from the Montebellos (Solem 1997). In Quistrachia, Solem (1997) distinguished Q. barrowensis from the earlier described $Q$. montebelloensis on the basis of minor differences in shell size and form. However, these differences are well within the range of variation seen within other species. For example, detailed study of Rhagada in the Dampier Archipelago showed that much larger differences in shell form need not indicate reproductively isolated species (Stankowski 2011). The high genetic similarities and the phylogenetic interspersion of COI haplotypes indicate that $Q$. barrowensis is the same species as $Q$. montebelloensis.

These genetic and revised taxonomic perspectives give a clearer basis for interpreting the history of the camaenid snails on Barrow Island. The large, endemic Rhagada is part of the major clade that dominates the mainland Pilbara (Johnson et al. 2012). In contrast, the small Rhagada is part of the morphologically diverse clade of the Dampier Archipelago, forming the western edge of that clade's geographic distribution. These two clades are geographically complementary, meeting only in the southern portion of the Burrup Peninsula (Johnson et al. 2012), on East and West Lewis Islands in the Dampier Archipelago (Stankowski, unpublished), and on Barrow Island. Thus, Barrow Island is biogeographically interesting, in showing an unusual coming together of very distinct lineages of Rhagada. The mutual exclusion of the two lineages on Barrow Island, however, also highlights a general feature of camaenid snails in Western Australia: congeneric species very seldom occur together (Solem 1997).

Such exclusion does not apply between genera, and Quistrachia and Rhagada overlap broadly on Barrow Island. The occurrence of $Q$. montebelloensis (including $Q$. barrowensis) on Barrow Island and in the Montebellos and Lowendals has different geographic origins from the similar distribution seen in $R$. plicata. Whereas the relatives of $R$. plicata lie to the east, in the Dampier Archipelago, the closest relatives of $Q$. montebelloensis are to the southwest: $Q$. lefroyi and $Q$. warroorana, from the Cape Range to near Shark Bay. Thus, taken together, the camaenid snails on Barrow Island, the Montebello Islands and the Lowendal Islands indicate different geographic origins of the island fauna. In their restriction to the islands, however, all three species are clear examples of short-range endemism, and hence special vulnerability (Harvey et al. 2011). The range of the Barrow Island endemic, $R$. barrowensis sp. nov., spans only $22 \mathrm{~km}$, with an area of about $250 \mathrm{~km}^{2}$. Even for R. plicata and Q. montebelloensis, whose distributions include the Montebellos and the Lowendals, the maximum distances between known populations are only $40 \mathrm{~km}$ and $70 \mathrm{~km}$, respectively, 
most of which is over water. The presence of these short-range endemics highlights the conservation significance of Barrow Island.

\section{SYSTEMATICS}

\section{Family Camaenidae Pilsbry, 1895 \\ Genus Quistrachia Iredale, 1939}

Quistrachia Iredale, 1939: 51-52.

\section{TYPE SPECIES}

Trachia monogramma Ancey, 1898, by original designation.

\section{REMARKS}

Based on Solem's (1997) revision and the present study, Quistrachia is a Western Australian endemic genus, including eight species, which occur between the Oscar Range and Dampier Land in the Kimberley, through the Pilbara, to Warroora Station, north of Shark Bay. The species have nonoverlapping geographic distributions.

\section{Quistrachia montebelloensis (Preston, 1914)}

Figures 1, 2, 6

Rhagada montebelloensis Preston, 1914: 13, Figure in text; Richardson, 1985: 265.

Globorhagada montebelloensis (Preston): Iredale, 1938: 114; Iredale, 1939: 73, Plate 5, Figure 20.

Quistrachia montebelloensis (Preston): Solem, 1997: 1827-1829, Plate 228a-b, Figure 440d-f.

Quistrachia barrowensis Solem, 1997: 1821-1827, Plates 227f, 232a-e, Figures 440a-c, 441a-c. New synonymy.

\section{TYPE LOCALITY}

Montebello Islands.

\section{MATERIAL EXAMINED}

Australia: Western Australia: Barrow Island: $20.7447^{\circ} \mathrm{S}, 115.3769^{\circ} \mathrm{E}$ (WAM S34699); $20.7616^{\circ} \mathrm{S}$, $115.3783^{\circ} \mathrm{E}$ (WAM S34697); $20.7666^{\circ} \mathrm{S}, 115.4000^{\circ} \mathrm{E}$ (WAM S5800, WAM S5801, WAM S8971, WAM S34696, WAM S14264); $20.7684^{\circ} \mathrm{S}, 115.4673^{\circ} \mathrm{E}$ (WAM $\mathrm{S} 10944) ; 20.7744^{\circ} \mathrm{S}, 115.4352^{\circ} \mathrm{E}$ (WAM S61309); $20.7753^{\circ} \mathrm{S}, 115.4684^{\circ} \mathrm{E}$ (WAM S10943); $20.7779^{\circ} \mathrm{S}$, $115.4702^{\circ} \mathrm{E}$ (WAM S14280); $20.7833^{\circ} \mathrm{S}, 115.4000^{\circ} \mathrm{E}$ (WAM S60827, WAM S61305, WAM S61297, WAM S61300, WAM S61311, WAM S61306, WAM S61854, WAM S61858, WAM S61855, WAM S61850, WAM
S61856, WAM S61857, WAM S61852, WAM S61853, WAM S61859); $20.7833^{\circ} \mathrm{S}, 115.3667^{\circ} \mathrm{E}$ (WAM S14256); $20.7847^{\circ} \mathrm{S}, 115.4575^{\circ} \mathrm{E}$ (WAM S65266); $20.7878^{\circ} \mathrm{S}$, $115.4624^{\circ} \mathrm{E}\left(\mathrm{WAM}\right.$ S61301); $20.7879^{\circ} \mathrm{S}, 115.4625^{\circ} \mathrm{E}$ (WAM S61307); $20.7882^{\circ} \mathrm{S}, 115.4628^{\circ} \mathrm{E}$ (WAM S61299); $20.7887^{\circ} \mathrm{S}, 115.4636^{\circ} \mathrm{E}$ (WAM S61302 ${ }^{\circ} \mathrm{S}$, (WAM S61304); $20.7892^{\circ} \mathrm{S}, 115.4625^{\circ} \mathrm{E}$ (WAM S61851); $20.7902^{\circ} \mathrm{S}, 115.4565^{\circ} \mathrm{E}$ (WAM S61298); $20.7908^{\circ} \mathrm{S}$, $115.4539^{\circ} \mathrm{E}(\mathrm{WAM} \mathrm{S} 84024) ; 20.7908^{\circ} \mathrm{S}, 115.4408^{\circ} \mathrm{E}$ (WAM S60828); $20.7923^{\circ} \mathrm{S}, 115.4385^{\circ} \mathrm{E}$ (WAM S61296, WAM S84049); $20.7961^{\circ} \mathrm{S}, 115.4536^{\circ} \mathrm{E}$ (WAM S65268); $20.7980^{\circ} \mathrm{S}, 115.3314^{\circ} \mathrm{E}$ (WAM S14258, WAM S14259); $20.7983^{\circ} \mathrm{S}, 115.4474^{\circ} \mathrm{E}$ (WAM S65261); $20.8000^{\circ} \mathrm{S}$, $115.3633^{\circ} \mathrm{E}$ (WAM S34695); $20.8000^{\circ} \mathrm{S}, 115.3500^{\circ} \mathrm{E}$ (WAM S84017, WAM S84023); $20.8009^{\circ} \mathrm{S}, 115.4544^{\circ} \mathrm{E}$ (WAM S61282); $20.8009^{\circ} \mathrm{S}, 115.4544^{\circ} \mathrm{E}$ (WAM S84020); $20.8022^{\circ} \mathrm{S}, 115.4467^{\circ} \mathrm{E}$ (WAM S84018); $20.8024^{\circ} \mathrm{S}$, $115.4483^{\circ} \mathrm{E}(\mathrm{WAM} \mathrm{S} 84050) ; 20.8057^{\circ} \mathrm{S}, 115.4507^{\circ} \mathrm{E}$ (WAM S60826); $20.8182^{\circ} \mathrm{S}, 115.3857^{\circ} \mathrm{E}$ (WAM S61176); $20.8205^{\circ} \mathrm{S}, 115.3856^{\circ} \mathrm{E}$ (WAM S84021); $20.8286^{\circ} \mathrm{S}$, $115.4444^{\circ} \mathrm{E}$ (WAM S14261); $20.8319^{\circ} \mathrm{S}, 115.4204^{\circ} \mathrm{E}$ (WAM S61173); $20.8438^{\circ} \mathrm{S}, 115.3817^{\circ} \mathrm{E}$ (WAM S34700); $20.8500^{\circ} \mathrm{S}, 115.3833^{\circ} \mathrm{E}$ (WAM S61860); $20.8661^{\circ} \mathrm{S}$, $115.4061^{\circ} \mathrm{E}$ (WAM S84019).

Double Island: $20.7333^{\circ} \mathrm{S}, 115.4833^{\circ} \mathrm{E}$ (WAM S60825, WAM S61165, WAM S84014).

Pascoe Island: $20.9610^{\circ} \mathrm{S}, 115.3396^{\circ} \mathrm{E}$ (WAM S61082); $20.9666^{\circ} \mathrm{S}, 115.3333$ (WAM S84027).

Lowendal Islands, Bridled Island: $20.6500^{\circ} \mathrm{S}$, $115.5669^{\circ} \mathrm{E}$ (WAM S12280). Varanus Island: $20.6556^{\circ} \mathrm{S}, 115.5766^{\circ} \mathrm{E}$ (WAM S83645, WAM S83625); $20.6556^{\circ} \mathrm{S}, 115.5782^{\circ} \mathrm{E}$ (WAM S83621, WAM S83634, WAM S83641); $20.6527^{\circ} \mathrm{S}, 115.5796^{\circ} \mathrm{E}$ (WAM S83644, WAM S83646, WAM S83638); $20.6512^{\circ} \mathrm{S}, 115.5802^{\circ} \mathrm{E}$ (WAM S83630); $20.6500^{\circ} \mathrm{S}, 115.5667^{\circ} \mathrm{E}$ (WAM S5684, WAM S5771, WAM S12278, WAM S61887, WAM S14366, WAM S12281); $20.6500^{\circ} \mathrm{S}, 115.5833^{\circ} \mathrm{E}$ (WAM S84015, WAM S84016); $20.6493^{\circ} \mathrm{S}, 115.5765^{\circ} \mathrm{E}$ (WAM S83624); $20.6482^{\circ} \mathrm{S}, 115.5732^{\circ} \mathrm{E}$ (WAM S83650, WAM S83640); $20.6476^{\circ} \mathrm{S}, 115.5709^{\circ} \mathrm{E}$ (WAM S83637, WAM S83643, WAM S83635, WAM S83639); 20.6459 ${ }^{\circ}$, $115.5692^{\circ} \mathrm{E}(\mathrm{WAM} \mathrm{S} 83631) ; 20.6446^{\circ} \mathrm{S}, 115.5682^{\circ} \mathrm{E}$ (WAM S83649, WAM S83651, WAM S83628); $20.6416^{\circ} \mathrm{S}, 115.5662^{\circ} \mathrm{E}$ (WAM S83623).

Montebello Islands, Unlisted Island: $20.4333^{\circ} \mathrm{S}$, $115.6167^{\circ} \mathrm{E}$ (WAM S5766); $20.4418^{\circ} \mathrm{S}, 115.5387^{\circ} \mathrm{E}$ (WAM S61083). Islet 1: $20.4486^{\circ} \mathrm{S}, 115.5267^{\circ} \mathrm{E}$ (WAM S5759). Islet 3: $20.4375^{\circ} \mathrm{S}, 115.5247^{\circ} \mathrm{E}$ (WAM S5764). Alpha Island: $20.4000^{\circ} \mathrm{S}, 115.5333^{\circ} \mathrm{E}$ (WAM S5758, WAM S5767); $20.4000^{\circ} \mathrm{S}, 115.5328^{\circ} \mathrm{E}$ (WAM $\mathrm{S} 12005) ; 20.4000^{\circ} \mathrm{S}, 115.5167^{\circ} \mathrm{E}$ (WAM S61886); $20.4166^{\circ} \mathrm{S}, 1^{115.5167^{\circ} \mathrm{E}}$ (WAM S84025). Crocus Island: $20.4166^{\circ} \mathrm{S}, 115.5167^{\circ} \mathrm{E}$ (WAM S12006). Bluebell Island: $20.4000^{\circ} \mathrm{S}, 115.5169^{\circ} \mathrm{E}$ (WAM S12004). Hermite Island: $20.4666^{\circ} \mathrm{S}, 115.5167^{\circ} \mathrm{E}$ (WAM S5760, WAM S5761, WAM S5762, WAM S5768, WAM S12244); $20.4420^{\circ} \mathrm{S}, 115.5320^{\circ} \mathrm{E}$ (WAM S61081); $20.4421^{\circ} \mathrm{S}$, $115.5328^{\circ} \mathrm{E}$ (WAM S61084). Trimouille Island: $20.4000^{\circ} \mathrm{S}, 115.5667^{\circ} \mathrm{E}$ (WAM S5757, WAM S5769). 


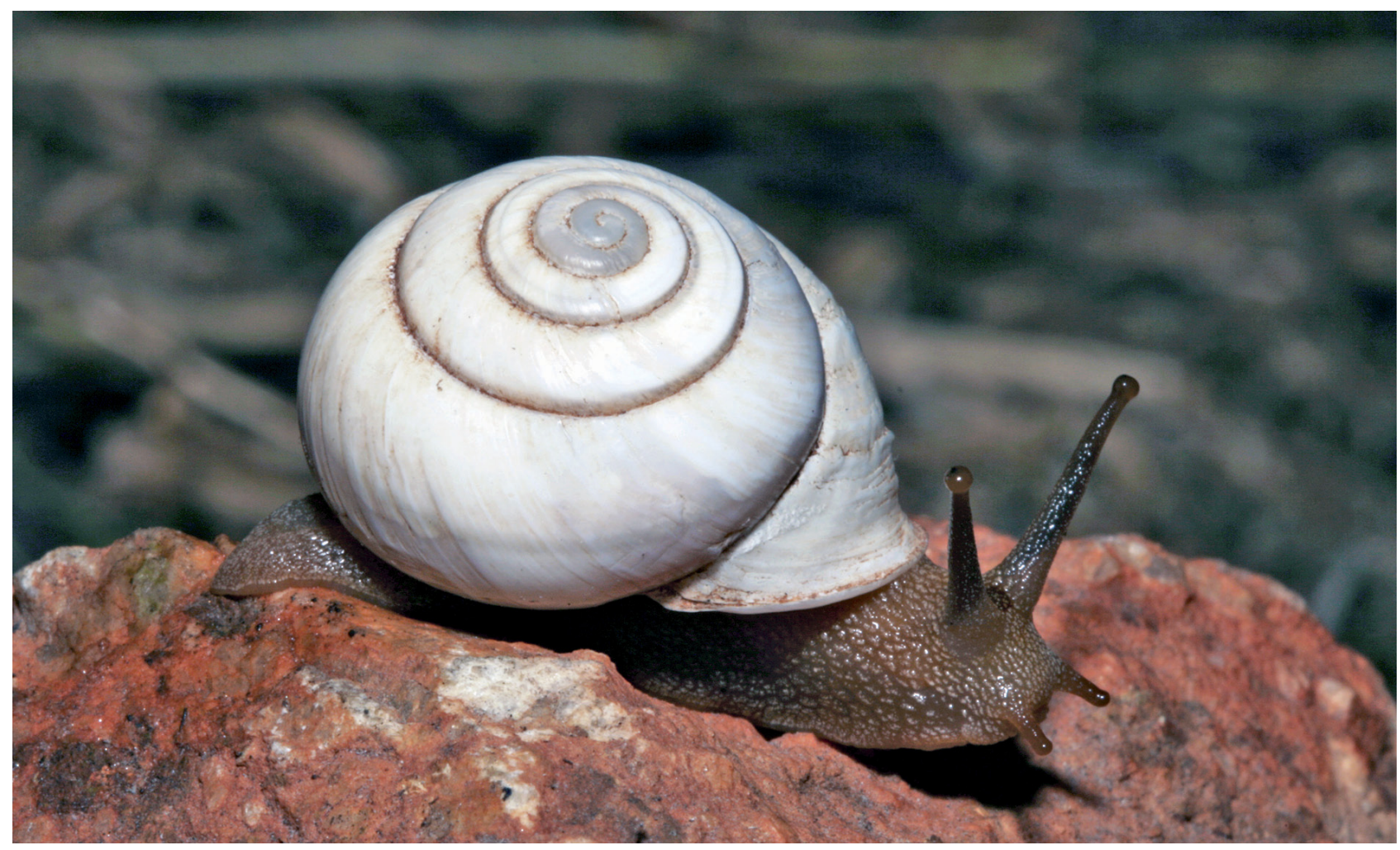

FIGURE 7 Live adult of Rhagada barrowensis sp. nov.

Near Ah Chong Island: $20.5152^{\circ} \mathrm{S}, 115.5444^{\circ} \mathrm{E}$ (WAM S5765); $20.5216^{\circ} \mathrm{S}, 115.5300^{\circ} \mathrm{E}$ (WAM S5770). North West Island: $20.4333^{\circ} \mathrm{S}, 115.6167^{\circ} \mathrm{E}$ (WAM S5763); $20.3666^{\circ} \mathrm{S}, 1^{115.5167^{\circ} \mathrm{E}}$ (WAM S12271).

\section{DISTRIBUTION}

Quistrachia montebelloensis is known from the Montebello Islands, Lowendal Islands and Barrow Island. It is also recorded from a few satellite islets off Barrow Island.

\section{REMARKS}

Solem (1997), who described $Q$ barrowensis, distinguished it from $Q$. montebelloensis based on subtle variation in shell size and thickness of the apertural lip. No comparative anatomical material of $Q$. montebelloensis was available at that time. Both nominal species are considered to be identical for the lack of molecular and morphological differentiation between the two island forms.

\section{Genus Rhagada Albers, 1860}

Rhagada Albers, 1860: 108-109.

\section{TYPE SPECIES}

Helix reinga 'Gray' Pfeiffer, 1846, by original designation.

\section{REMARKS}

With 38 described species, Rhagada is second most diverse camaenid genus in Western Australia, behind the Kimberley genus Amplirhagada (Solem 1997, Köhler 2011). Species are allopatric, distributed from the Mitchell Plateau in the Kimberley to Shark Bay. Additional species occur in Indonesia (Maassen 2009).

\section{Rhagada barrowensis sp. nov.}

Figures 1, 3, 4, 7, 8

urn:Isid:zoobank.org:act:48D0D0F1-5488-47FC-9B999F03B75DD389

\section{TYPE LOCALITY}

Australia: Western Australia: Pilbara, Barrow Island, Terminal Tanks Road South, $20.8182^{\circ} \mathrm{S}$, $115.4383^{\circ} \mathrm{E}, 18$ March 2004, J. Fitzpatrick, L15 (Triodia angusta dominated plain).

\section{MATERIAL STUDIED}

\section{Holotype}

WAM 584062 (preserved specimen).

\section{Paratypes}

Australia: Western Australia: Barrow Island: 
WAM S84063 (7 preserved, 1 dissected specimens) from $20.8182^{\circ} \mathrm{S}, 115.4383^{\circ} \mathrm{E}$; WAM S84064 (8 preserved specimens) from $20.8184^{\circ} \mathrm{S}, 115.3256^{\circ} \mathrm{E}$; WAM S84065 (8 preserved specimens) from $20.7316^{\circ} \mathrm{S}, 115.4691^{\circ} \mathrm{E}$; WAM S84066 (8 preserved specimens) from $20.8502^{\circ} \mathrm{S}, 115.4157^{\circ} \mathrm{E}$; WAM $S 84067$ (8 preserved specimens) from $20.6714^{\circ} \mathrm{S}, 115.4420^{\circ} \mathrm{E}$; WAM S84068 (8 preserved specimens) from $20.7800^{\circ} \mathrm{S}, 115.3940^{\circ} \mathrm{E}$.

\section{Other material examined (Non-types)}

Australia: Western Australia: Barrow Island: $20.7666^{\circ} \mathrm{S}, 115.4000^{\circ} \mathrm{E}$ (WAM S5681, WAM S6171, WAM S8799, WAM S8803, WAM S8813, WAM S8853, WAM S8854, WAM S14253, WAM S14262); $20.7500^{\circ} \mathrm{S}$, $115.3667^{\circ} \mathrm{E}$ (WAM S9070); $20.7666^{\circ} \mathrm{S}, 115.4000^{\circ} \mathrm{E}$ (WAM S10942); $20.7753^{\circ} \mathrm{S}, 115.4575^{\circ} \mathrm{E}$ (WAM S10947); $20.7833^{\circ} \mathrm{S}, 1^{115.3667^{\circ} \mathrm{E}}$ (WAM S14255); 20.8000 ${ }^{\circ} \mathrm{S}$, $115.3633^{\circ} \mathrm{E}$ (WAM S14257); $20.7753^{\circ} \mathrm{S}, 115.4684^{\circ} \mathrm{E}$ (WAM S14277); $20.7616^{\circ} \mathrm{S}, 115.3783^{\circ} \mathrm{E}$ (WAM S34698); $20.8438^{\circ} \mathrm{S}, 115.3817^{\circ} \mathrm{E}$ (WAM S34701); $20.7833^{\circ} \mathrm{S}$, $115.4000^{\circ} \mathrm{E}$ (WAM S59285, WAM S61849); $20.8229^{\circ} \mathrm{S}$, $115.3725^{\circ} \mathrm{E}$ (WAM S61167); 20.8144 ${ }^{\circ} \mathrm{S}, 115.3756^{\circ} \mathrm{E}$ (WAM S61168); $20.8414^{\circ} \mathrm{S}, 115.3898^{\circ} \mathrm{E}$ (WAM S61169); $20.8055^{\circ} \mathrm{S}, 115.4312^{\circ} \mathrm{E}$ (WAM S61170); $20.8191^{\circ} \mathrm{S}$, $115.3944^{\circ} \mathrm{E}$ (WAM S61171); $20.7927^{\circ} \mathrm{S}, 115.4242^{\circ} \mathrm{E}$ (WAM S61174); $20.7966^{\circ} \mathrm{S}, 115.3528^{\circ} \mathrm{E}$ (WAM S61175); $20.8024^{\circ} \mathrm{S}, 115.4483^{\circ} \mathrm{E}$ (WAM S64901); $20.7887^{\circ} \mathrm{S}$, $115.4636^{\circ} \mathrm{E}$ (WAM S64902); $20.7879^{\circ} \mathrm{S}, 115.3958^{\circ} \mathrm{E}$ (WAM S64903); $20.7881^{\circ} \mathrm{S}, 115.4627^{\circ} \mathrm{E}$ (WAM S64906); $20.7882^{\circ} \mathrm{S}, 115.4628^{\circ} \mathrm{E}$ (WAM S64907); 20.7977 ${ }^{\circ} \mathrm{S}$, $115.4064^{\circ} \mathrm{E}$ (WAM S64909, WAM S64917); $20.8009^{\circ} \mathrm{S}$, $115.4544^{\circ} \mathrm{E}$ (WAM S64910, WAM S84046); $20.7866^{\circ} \mathrm{S}$, $115.4547^{\circ} \mathrm{E}$ (WAM S64914); $20.7869^{\circ} \mathrm{S}, 115.4492^{\circ} \mathrm{E}$ (WAM S64915); $20.7944^{\circ} \mathrm{S}, 115.4557^{\circ} \mathrm{E}$ (WAM S64918); $20.8205^{\circ} \mathrm{S}, 115.3856^{\circ} \mathrm{E}$ (WAM S64921, WAM S84022); $20.7892^{\circ} \mathrm{S}, 115.4621^{\circ} \mathrm{E}\left(\mathrm{WAM}\right.$ S65264); $20.7833^{\circ} \mathrm{S}$, $115.3667^{\circ} \mathrm{E}$ (WAM S84026); $20.7500^{\circ} \mathrm{S}, 115.3667^{\circ} \mathrm{E}$ (WAM S84031); $20.8833^{\circ} \mathrm{S}, 115.3167^{\circ} \mathrm{E}$ (WAM S84032); $20.8000^{\circ} \mathrm{S}, 115.4000^{\circ} \mathrm{E}$ (WAM S84033); $20.8268^{\circ} \mathrm{S}$, $115.4455^{\circ} \mathrm{E}(\mathrm{WAM} \mathrm{S} 84045) ; 20.7950^{\circ} \mathrm{S}, 115.4577^{\circ} \mathrm{E}$ (WAM S84047); 20.8798 ${ }^{\circ}$ S, $115.3966^{\circ} \mathrm{E}$ (WAM S84048).

Boodie Island: $20.9666^{\circ} \mathrm{S}, 115.3333^{\circ} \mathrm{E}$ (WAM S84028).

\section{DIAGNOSIS}

Rhagada barrowensis possesses a large (mean diameter $20.9 \mathrm{~mm}$ ), white shell with a brown to orange supra-peripheral band and generally no accessory banding. It differs in size (larger) and shell sculpture (smoother) from the nearby $R$. plicata. R. perprima from the Dampier Archipelago has more prominent supra-peripheral and subsutural banding. It is difficult to separate $R$. barrowensis from some members of the genus ( $R$. convicta and $R$. pilbarana) based exclusively on shell features. Anatomically its very long, tapering penial verge and a spermatheca that is strongly kinked near the apex are distinctive.

\section{DESCRIPTION}

Shell (Figures 1 and 7, Table 2) solid, large for the genus, adult diameter 17.75-22.80 mm (mean 20.96, sd $0.92 \mathrm{~mm}$ ), height $14.80-18.25 \mathrm{~mm}$ (mean 16.33, sd $1.12 \mathrm{~mm}$ ), with 5.00-6.05 (mean 5.72, sd 0.17) rather tightly coiled, rounded convex whorls. Spire strongly elevated; body whorl large with evenly rounded periphery; protoconch short, translucent grey to light blue (when fresh), predominantly smooth with traces of very fine radial sculpture; teleoconch with regular radial growth ridgelets; umbilicus always closed (adults); body whorl descending noticeably behind lip, which is broadly expanded to form a sharp thickened rim; shell background colour white with narrow brown to orange supra-peripheral band present, ranging from very distinct to just visible; usually narrow (occasionally wide) subsutural band present on

TABLE 2

Shell variation in Rhagada barrowensis sp. nov. The grand mean excludes data for the holotype specimen. $\mathrm{n}$, number of adult shells measured. Measurements in $\mathrm{mm}$.

\begin{tabular}{llllll} 
WAM number & $n$ & shell height $(\mathrm{sd})$ & shell diameter $(\mathrm{sd})$ & H/D ratio (sd) & No. whorls (range) \\
\hline S84062 (holotype) & 1 & 17.10 & 22.66 & 0.75 & 5.80 \\
S84063 & 8 & $17.03(0.82)$ & $21.23(1.10)$ & $0.80(0.03)$ & $5.71(5.65-5.80)$ \\
S84064 & 8 & $15.36(0.47)$ & $20.10(1.13)$ & $0.77(0.04)$ & $5.74(5.65-5.80)$ \\
S84065 & 8 & $16.28(1.03)$ & $21.25(1.16)$ & $0.77(0.05)$ & $5.53(5.00-5.80)$ \\
S84066 & 8 & $16.40(0.59)$ & $20.48(0.82)$ & $0.80(0.03)$ & $5.81(5.65-6.00)$ \\
S84067 & 8 & $16.49(0.90)$ & $21.56(0.68)$ & $0.77(0.04)$ & $5.81(5.60-6.05)$ \\
Grand mean & & $16.31(0.60)$ & $20.92(0.60)$ & $0.78(0.02)$ & $5.72(5.00-6.05)$ \\
\hline
\end{tabular}




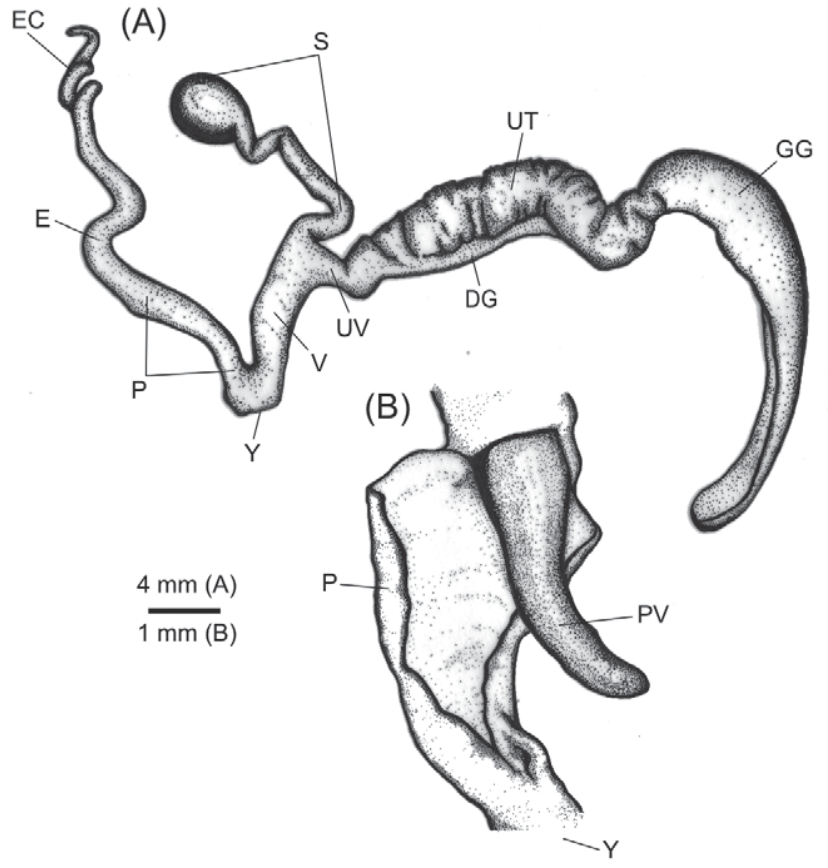

FIGURE 8 Reproductive system (A) and penial anatomy (B) of Rhagada barrowensis sp. nov. Abbreviations: GG, albumen gland; UT, uterus; DG, prostate; UV, oviduct; $S$, spermatheca; $V$, vagina; $Y$, atrium; $P$, penis, E, epiphalus; EC. Epiphalic caecum; PV, penial verge. All notation follow Solem (1997).

all whorls, usually faded but occasionally distinct, continuous with protoconch; very occasionally traces of narrow accessory bands (1-4) on shell base. Based on 41 measured adults (types).

Reproductive system (Figure 8) with large albumen gland (GG), similar in length to uterus (UT); short, free oviduct (UV); long spermatheca (S) with strong kinks near the apex; vagina (V) and penis $(\mathrm{P})$ of a similar, medium length; vagina wider than penis; long epiphallus (E); epiphalic caecum (EC) long and tightly coiled; penial verge (PV) with smooth surface, very long and tapering, nearly three-quarters length of penis; interior penial wall smooth.

\section{COMPARATIVE REMARKS}

The shells of $R$. barrowensis closely resemble $R$. convicta. The two species cannot be reliably distinguished by their shell colour, banding and dimensions. Rhagada perprima is also similar in colour, shell dimensions, and occasionally banding pattern, but tends to have a more prominent supra-peripheral band and subsutural banding. $R$. pilbarana can be distinguished by presence of a prominent, red supra-peripheral band. Rhagada barrowensis and $R$. plicata, the other species of Rhagada known from Barrow Island, can be readily distinguished based on their shell diameter (17.75-22.80 $\mathrm{mm}$ and $9.00-12.05 \mathrm{~mm}$, respectively) and pattern of sculpturing of the spire and body whorl (smooth and strongly ribbed, respectively). Rhagada barrowensis is often found in sympatry with Q. montebelloensis, but can be distinguished based by its larger shell (mean diameters of $20.92 \mathrm{~mm}$ and $15.13 \mathrm{~mm}$, respectively), absence of an umbilical chink (adults) and less sculpture on the shell protoconch (almost smooth versus distinct radial riblets, respectively).

Anatomically $R$. barrowensis differs from $R$. convicta in several ways. $R$. barrowensis has a very long tapering penial verge, nearly three-quarters the length of the penis, while $R$. convicta has small triangular verge with a corrugated surface. Also $R$. convicta has a spermatheca that is only slightly kinked near the middle, while that of $R$. barrowensis is strongly kinked near the apex. $R$. barrowensis and $R$. pilbarana have similar reproductive systems, though the spermatheca of $R$. pilbarana is sharply kinked near the middle rather than at the terminal end, and, while elongated, the penial verge of $R$. pilbarana is club-shaped instead of tapering. $R$. plicata has a much shorther penial verge with a corrugated, rather than smooth, surface.

\section{DISTRIBUTION}

This species is recorded from Barrow Island and its southern satellite Boodie Island (Figure 4).

\section{REMARKS}

Solem (1997) did not list any species of Rhagada from Barrow Island, although he had previously identified some specimens from Barrow Island in the collections of the WA Museum as Rhagada tescorum Benson, 1853 (type locality Shark Bay), a species that he did not mention in the section dealing with the genus Rhagada (Solem 1997) or in later publications on the Western Australian snail fauna. In their physiological study, Withers et al. (1997) tentatively used the name $R$. tescorum for this species, but this was incorrect. Examination of Solem's rather large number ( 70 lots) of mainland $R$. tescorum in the WA Museum collection suggests it is a complex of other named Rhagada species. Smith (1992) listed R. tescorum as incertae sedis because of a dispute on where the holotype was held, but it could also have been because of the uncertainty of where to place the species.

Some long-dead, mostly juvenile shells from Hermite Island (WAM S5761, WAM S6243, WAM S12244, WAM S12272) and Varanus Island (WAM S12282) in the WA Museum collection resemble $R$. barrowensis but were unsuitable for comparison. 


\section{ETYMOLOGY}

For Barrow Island, adjective.

\section{Rhagada plicata Preston, 1914}

Rhagada plicata Preston, 1914: 13-14, Figure in text; Hedley, 1916: 70; Solem, 1997: 1737-1741, Plates 207a, 221a-d, Figures 418a-b, 419a-c.

Bellrhagada plicata (Preston): Iredale, 1938: 114; Iredale, 1939: 71, Plate 5, Figure 16; Richardson, 1985: 65.

Rhagada sp. (small) Johnson et. al., 2006: Figure 1.

\section{TYPE LOCALITY}

Montebello Islands.

\section{MATERIAL EXAMINED}

Australia: Western Australia: Barrow Island: $20.6665^{\circ} \mathrm{S}, 115.4389^{\circ} \mathrm{E}$ (WAM S6168); $20.6836^{\circ} \mathrm{S}$, $115.4645^{\circ} \mathrm{E}$ (WAM S64919); $20.6816^{\circ} \mathrm{S}, 115.4689^{\circ} \mathrm{E}$ (WAM S64920); 20.6783ㅇ, $115.4167^{\circ} \mathrm{E}$ (WAM S28091); $20.6733^{\circ} \mathrm{S}, 115.4491^{\circ} \mathrm{E}$ (WAM S64904); 20.6712 ${ }^{\circ} \mathrm{S}$, $115.4373^{\circ} \mathrm{E}$ (WAM S64900, WAM S64913); $20.6709^{\circ} \mathrm{S}$, $115.4370^{\circ} \mathrm{E}$ (WAM S64911); $20.6808^{\circ} \mathrm{S}, 115.4683^{\circ} \mathrm{E}$ (WAM S10948).

Lowendal Islands, Varanus Island: $20.6574^{\circ} \mathrm{S}$, $115.5774^{\circ} \mathrm{E}$ (WAM S83629, WAM S83648); 20.6556 ${ }^{\circ}$, $115.5766^{\circ} \mathrm{E}$ (WAM S83626, WAM S83636); 20.6556 ${ }^{\circ}$, $115.5782^{\circ} \mathrm{E}$ (WAM S83622, WAM S83647).

Montebello Islands: Alpha Island: $20.4000^{\circ} \mathrm{S}$, $115.5333^{\circ} \mathrm{E}$ (WAM S6014); $20.4000^{\circ} \mathrm{S}, 115.5328^{\circ} \mathrm{E}$ (WAM S12009). Bluebell Island: $20.4000^{\circ} \mathrm{S}, 115.5169^{\circ} \mathrm{E}$ (WAMS 12007). Brooke Island: $20.4333^{\circ} \mathrm{S}, 115.5000^{\circ} \mathrm{E}$ (WAM S6244). Hermite Island: $20.4838^{\circ} \mathrm{S}, 115.5294^{\circ} \mathrm{E}$ (WAM S84013); $20.4666^{\circ} \mathrm{S}, 115.5167^{\circ} \mathrm{E}$ (WAM S28108, WAM S6009, WAM S6017, WAM S84012, WAM S84034). North West Island: $20.3680^{\circ} \mathrm{S}, 115.5332^{\circ} \mathrm{E}$ (WAM S61086); $20.3666^{\circ} \mathrm{S}, 115.5167^{\circ} \mathrm{E}$ (WAM S6015). Primrose Island: $20.3719^{\circ} \mathrm{S}, 115.5194^{\circ} \mathrm{E}$ (WAM S61085). Trimouille Island: $20.4000^{\circ} \mathrm{S}, 115.5667^{\circ} \mathrm{E}$ (WAM S6016).

\section{DISTRIBUTION}

Rhagada plicata is known from the Montebello Islands, Lowendal Islands (Varanus Island) and the northern portion of Barrow Island.

\section{REMARKS}

In his section on $R$. plicata, Solem (1997) mentioned a few specimens found on Barrow Island that were unsuitable for description or taxonomic placement. Presumably those specimens were long-dead, worn $R$. plicata shells.

\section{ACKNOWLEDGEMENTS}

Gemma Fitzpatrick helped with the genetic analyses, which were funded by Rio Tinto and Woodside Energy. The 2009 collections in the Montebello Islands and on Boodie and Pascoe Islands were made possible by a DEC Landscope expedition. Volker Framenau (Phoenix Environmental Services) provided specimens from Varanus Island, and Peter Kendrick (DEC) provided additional samples from Barrow Island.

\section{REFERENCES}

Davison, A., Blackie, R.L.E., and Scothern, G.P. (2009). DNA barcoding of stylommatophoran land snails: a test of existing sequences. Molecular Ecology Resources 9: 1092-1101.

Davison, A., and Clarke, B. (2000). History or current selection? A molecular analysis of 'area effects' in the land snails Cepaea nemoralis. Proceedings of the Royal Scoiety of London B 267: 1-8.

Goodacre, S.L. (2002). Population structure, history and gene flow in a group of closely related land snails: genetic variation in Partula from the Society Islands of the Pacific. Molecular Ecology 11: 55-68.

Harvey, M.S., Rix, M.G., Framenau, V.W., Hamilton, Z.R., Johnson, M.S., Teale, R.J., Humpreys, G., and Humphreys, W.F. (2011). Protecting the innocent: studying short-range endemic taxa enhances conservation outcomes. Invertebrate Systematics 25: 1-10.

Iredale, T. (1938). A basic list of the land Mollusca of Australia. Part III. Australian Journal of Zoology 9: 83-124.

Iredale, T. (1939). A review of the land Mollusca of Western Australia. Journal of the Royal Society of Western Australia 25: 1-88.

Johnson, M.S., Hamilton, Z.R., and Fitzpatrick, J. (2006). Genetic diversity of Rhagada land snails on Barrow Island. Journal of the Royal Society of Western Australia 89: $45-50$.

Johnson, M.S., Hamilton, Z.R., Teale, R., and Kendrick, P.G. (2012). Endemic evolutionary radiation of Rhagada land snails (Pulmonata: Camaenidae) in a continental archipelago in northern Western Australia. Biological Journal of the Linnean Society 106: 316-327.

Johnson, M.S., Murray, J., and Clarke, B. (1993). The ecological genetics and adaptive radiation of Partula on Moorea. Oxford Surveys in Evolutionary Biology 9: 167-238.

Johnson, M.S., Stine, O.C., and Murray, J. (1984). Reproductive compatibility despite large-scale genetic divergence in Cepaea nemoralis. Heredity 53: 655-665.

Köhler, F. (2011). The camaenid species of the Kimberley islands, Western Australia (Stylommatophora: Helicoidea). Malacologia 54: 203-406.

Köhler, F., and Johnson, M.S. (2012). Species limits in molecular phylogenies: A cautionary tale from Australian land snails (Camaenidae: Amplirhagada Iredale, 1933). Zoological Journal of the Linnean Society 165: 337-362. 
Maassen, W.J.M. (2009). A new Rhagada species from Alor Island, Lesser Sunda Islands, Indonesia (Gastropoda, Pulmonata, Camaenidae). Miscellanea Malacologica 3: 65-69.

O'Neill, C. (2008). The relationship between morphology and genetics in Quistrachia (Gastropoda: Pulmonata) from the Pilbara, Western Australia. Zoology Honours thesis, School of Animal Biology, University of Western Australia.

Pinceel, J., Jordaens, K., and Backeljau, T. (2005). Extreme mtDNA divergences in a terrestrial slug (Gastropoda, Pulmonata, Arionidae): accelerated evolution, allopatric divergence and secondary contact. Journal of Evolutionary Biology 18: 1264-1280.

Preston, H.B. (1914). Description of new species of land and marine shells from the Montebello Islands, Western Australia. Proceedings of the Malacological Society, London 11: 13-18.

Richardson, L. (1985). Camaenidae: Catalog of species. Tyronia 12: 1-479.

Slack-Smith, S.M. (2002). A preliminary survey of the terrestrial molluscan fauna within and adjacent to the land-based component of the proposed Gorgon Development, Barrow Island, Western Australia. Report to Gorgon Venture, Appendix H.

Solem, A. (1997). Camaenid land snails from Western and Central Australia (Mollusca: Pulmonata: Camaenidae). VII. Taxa from Dampierland through the Nullarbor. Records of the Western Australian Museum, Supplement 50: 1461-1906.

Stankowski, S. (2011). Extreme, continuous variation in an island snail: local diversification and association of shell form with the current environment. Biological Journal of the Linnean Society 174: 756-769.

Tamura, K., Peterson, D., Peterson, N., Stecher, G., Nei, M., and Kumar. S. (2011). MEGA5: molecular evolutionary genetics analysis using maximum likelihood, evolutionary distance, and maximum parsimony methods. Molecular Biology and Evolution 28: 2731-2739.

Thomaz, D., Guiller, A., and Clarke, B. (1996). Extreme divergence of mitochondrial DNA withinspecies of pulmonate land snails. Proceedings of the Royal Society of London. Series B 263: 363-368.

Withers, P., Pedler, S., and Guppy, M. (1997). Physiological adjustments during aestivation by the Australian land snail Rhagada tescorum (Mollusca: Pulmonata: Camaenidae). Australian Journal of Zoology 45: 699-611.

MANUSCRIPT RECEIVED 1 NOVEMBER 2012; ACCEPTED 1 MARCH 2013. 